\title{
1
}

\section{September 11, 2001, as a Teachable Moment}

\section{Edward Zlotkowski}

Bentley College

The Opening Plenary at the 2001 POD Conference was given by Edward Zlotkowski. Using the reactions to the events of September 11, 2001, as an example, he urged those in higher education to search out opportunities for academically based civic engagement and to focus on Boyer's concept of the scholarship of engagement.

\section{INTRODUCTION}

n September 11, 2001, late in the afternoon, an email message went out from the undergraduate dean of my institution (C. Hadlock, personal communication, September 11, 2001). It began as follows:

To follow up on [the college president's] message, most of the faculty I have talked to agree that we will all find various kinds of benefits in further discussion of today's events in classes tomorrow... Students who typically see teachers as presenters of academic material in a narrow discipline have much to learn from witnessing our universal concern for the issues raised by the tragedy...

Therefore, I would encourage everyone to make an effort to raise some of these issues for discussion. There is no single discipline that owns the subject of human tragedy, nor is there any faculty member who would not have valuable points of view to share with his or her classes. 
That the dean should publicly recognize the "narrow" disciplinary identities most faculty offer their students and the way in which such identities are immediately challenged by events of "universal concern" struck me as both admirable and sad. Was this also the identity I shared with my students? Did the way in which I typically presented my material leave them feeling disconnected from universal concerns?

Two days later another message (J. Morone, personal communication, September 13, 2001) with a very similar theme was sent from our president. Again, faculty were encouraged "if possible to connect the events around us to the content of your subject and discipline." Recognizing that some faculty might well be "uncomfortable about this, or... not sure how to proceed," he suggested they contact the undergraduate dean, their chair, or a "colleague who might be able to help." It seems as though the dean's encouragement had not had the desired results.

I've received a number of emails from faculty reporting that they had wonderful sessions yesterday. Unfortunately, I've also received emails from students expressing disappointment that their professors barely mentioned what was going on around us before launching into their scheduled lectures. Our job as educators today and tomorrow and for quite some time to come is to help our students, as best we can, to make sense of all this. And for every discipline, surely there are connections that can and should be made berween the tragedy our students are living through and the subjects we teach.

It would be for me hard to find a casual document that so clearly suggested what is wrong with contemporary American higher education. The gap between faculty performance and student expectations, the recognition that our job as educators now demands more than business as usual, the almost plaintive suggestion that surely there are connections between what we live and what we teach-these all suggest what the late Donald Schon (1995) called "the dilemma of rigor or relevance" (p. 28). It is a dilemma that has been growing in visibility over the past ten years, a dilemma the events of September 11 and their aftermath powerfully drive home.

\section{The Post-Cold War Academy}

Whether or not most academics now recognize it, the end of the Cold War may emerge as a watershed event not just in international relations but also in American higher education. While the Clark Kerr $(1963,1994)$ of the early 
1960s "was generally optimistic about the workings of the knowledge process" (p. 155), celebrating the triumph of what he called the "multiversity" as an "imperative rooted in the logic of history" (p. 5), the Kerr of the early 1990s had "more reservations" (p. 155):

New knowledge, like addictive drugs, can have bad as well as good effects. And new knowledge has limits to its curative effects, as in directly controlling the population explosion or the eruption of ethnic and religious fundamentalism. Knowledge is not clearly all good, and certainly not the one and only "one good." The university, consequently, needs to be more careful in what it does and less arrogant about what it claims it can do. So many of us should have realized all of this more fully so much earlier. We were too euphoric. (p. 155)

This new recognition that knowledge for its own sake-still the mantra of most elite institutions-is not the unambiguous, self-sufficient good many academics like to assert it is and that university-generated knowledge cannot even begin to address many of our most important social problems may have been long overdo, but it was the end of the Cold War that allowed it to surface. As R. C. Lewontin (1997) points out,

Although the power to command... favorable conditions of employment [as a result of government investment in research] accrues at first-hand to established academics in the natural and some of the social sciences, primarily at large research universities, it has changed the relationship between institutions and academics generally.... Lower teaching loads in science have meant lower teaching loads in the humanities. (p. 130)

Indeed, the availability of research money did more than tip the balance toward research and away from students. It also reinforced a trend evident from the earliest decades of the modern university to substitute disciplinary stature for local engagement (Lewontin, 1997). Government funding and an assumption of national importance aided and abetted a "guild mentality" that Kerr $(1963,1994)$ characterizes as "isolationist toward society, devoted to producer as against consumer sovereignty, and committed more to guild rules than to quick adaptation to popular demand" (p. 73).

For many faculty, this guild mentality is still a boon devoutly to be wished, but, unfortunately for them, neither governmental largesse nor public attitudes 
make its future prospects bright. Frank Newman (2000), Director of the Futures Project: Policy for Higher Education in a Changing World, notes that

over the long history of higher education, universities and collegesboth state-owned and private-have held a privileged position because they have focused on the needs of society rather than self-gains. They have, in turn, been given special responsibilities. As higher education becomes more closely linked to for-profit activities and market forces, its special status is endangered. (p. 16)

What exactly are the special responsibilities American higher education has assumed now that the ideological contest with the former Soviet Union has been won, and the technological superiority the academy helped the country achieve is no longer needed in quite the same way? Speaking to a gathering of Jesuit educators at Santa Clara University in fall 2000, Peter-Hans Kolvenbach, the order's Superior General, commented on some of the ramifications of this change:

This valley [Silicon Valley], this nation and the whole world look very different from the way they looked twenty-five years ago. With the collapse of Communism and the end of the Cold War, national and even international politics have been eclipsed by a resurgent capitalism that faces no ideological rival. (p. 5)

As a result,

all American universities, [Jesuit] included, are under tremendous pressure to opt entirely for success [in the sense of placing graduates in high-paying jobs]. But what our students want-and deserve-includes but transcends this "worldly success" based on marketable skills. (Kolvenbach, 2000, p. 6)

This is the same emphasis on private gain Newman (2000) warns against. Indeed, it is the very same phenomenon Boyer (1996) warned against in one of his very last publications.

In an essay published posthumously in the inaugural issue of the Journal of Public Service and Outreach, Boyer (1996) anticipated precisely the analysis made by Newman and Kolvenbach. After lamenting the faculty's increasingly evident intellectual insularity, he identifies a second, related trend: 
But, what I find most disturbing... is a growing feeling in this country that higher education is, in fact, part of the problem rather than the solution. Going still further, that it's become a private benefit, not a public good. Increasingly, the campus is being viewed as a place where students get credentialed and faculty get tenured, while the overall work of the academy does not seem particularly relevant to the nation's most pressing civic, social, economic, and moral problems. (p. 14)

The suggestion that higher education may now be part of the problem rather than the solution has several dimensions. First and foremost, it implies the lack of a guiding public purpose just alluded to. However, it also implies an at least implicit collaboration with elitist, anti-democratic forces and purely market-driven mechanisms. Recent studies indicating that the most accurate predictor of a college education is family income, the increasing interchangeability of university presidents and corporate CEOs (Lind, 1995), the growing reliance of many higher education institutions on poorly compensated parttime instructors as well as the wage-scale differential between those instructors and the academic "stars" who move from institution to institution selling their reputations to the highest bidder all suggest that the academy's own operations are far closer to a corporate model than the trumpeted ideal of a community of scholars would lead the public to suspect.

But the disturbing situation Boyer (1996) refers to has its roots in something far deeper than such cross-sector institutional parallels; it also reflects the intellectual assumptions that continue to ground most faculty work-in practice, if not in theory. Harry Boyte (2000), among others, has identified this set of assumptions with the still powerful legacy of positivism:

The ideal of the detached scholar, teacher, and outside expert has roots in the impact of German universities on American scholars in the late nineteenth century, as the Princeton historian Daniel Rodgers has described in Atlantic Crossings. American economic graduate students learned an ethos of scientific "objectivity" and a model of policy making in private consultation with political leadership, far removed from public involvement. The ethos of detachment was further fed by an uncritical celebration of science, and especially by the philosophers of positivism, who argued that science rested on the discovery of permanent, atemporal standards of rationality that could be found and then applied. (p. 46) 
Hence, "everywhere the sense of detachment and the stance of 'objectivity' which are positivism's legacy lead to isolation and competition" and encourage professionals to "imagine themselves outside a shared reality with their fellow citizens" (p. 50).

It is also to this legacy that Sullivan (n.d.), in a recent essay entitled "Institutional Identity and Social Responsibility," attributes what he calls the "default program of instrumental individualism" (p. 8) that defines most of the contemporary academy's work:

In the absence of an updated version of its founding conception of itself as a participant in the life of civil society, as a citizen of American democracy, much of higher education has come to operate on a sort of default program of instrumental individualism. This is the familiar notion that the academy exists to research and disseminate knowledge and skills as tools for economic development and the upward mobility of individuals. This "default program" of instrumental individualism leaves the larger questions of social, political, and moral purpose out of explicit consideration. (p. 2)

In adopting the phrase "default program" [emphasis added], Sullivan succinctly captures both the pervasiveness and the insidiousness of the academy's lack of a defining public vision: the failure of most faculty to pursue work that clearly articulates and advances some sense of the public good perforce results in teaching and scholarship that reinforces a dysfunctional status quo-regardless of an activity's particular content or focus. As Boyte (2000) notes, "Positivism structures our research, our disciplines, our teaching, and our institutions long after it has been discredited intellectually. It is like a genie that academia let loose long ago, now lurking below the surface and threatening our destruction" (p. 48).

Hence, it is hardly surprising that the faculty response to the events of September 11, 2001, should have been in many instances disappointing. Although more and more faculty recognize the importance of paying more attention to civic engagement, most continue to see this attention as somebody else's business. According to research conducted by the Higher Education Research Institute (1999),

Faculty are increasingly likely to believe that American colleges and universities are committed to involving students in community service. ... Between 1989 and 1998, the percent of faculty who believe that their institution places a priority on facilitating student involvement in 
community service has grown from 23 to 36 percent" (Community Service and Social Activism section, I 1). However,

Despite the faculty's growing awareness of their institution's commitment to community service, such trends are not evident with respect to the faculty's personal commitment to community service and social activism. Since 1989, a declining percentage of faculty are personally committed to such goals as influencing the political structure, influencing social values, and cleaning up the environment.... And although 54 percent of faculty believe that "community service should be given weight in college admissions" (up from 47 percent in 1995), there has been essentially no change in faculty's own commitment to "instill in students a commitment to community service" and to "prepare students for responsible citizenship." [emphasis added] (Higher Education Research Institute, 1999, Community Service and Social Activism section, I 2)

Under such circumstances, it should not be surprising that even when faced with a public event of historic proportions, many faculty are simply unable-psychologically, conceptually, pedagogically - to make a meaningful connection between that event and their professional work. Indeed, the very idea of doing so must seem to many of them rather unprofessional! (See, for example, Howard, 2001.) To respond to a public event means to be willing to suspend, to bracket the "real" work of a class, to siphon precious time and energy away from the primary work at hand: a distanced, detached consideration of largely prepackaged, self-referential material. The idea that there exist natural "connections that can and should be made between [what] our students are living through and the subjects we teach" [emphasis added] (J. Morone, personal communication, September 2001) must seem, at best, puzzling. What more can one demand from faculty than that they be willing to make time for conscientious "personal" reactions?

\section{The Engaged Campus and the Scholarship of Engagement}

It is in response to this disabling and ultimately dysfunctional professional disengagement from public life that the civic engagement movement of the last decade has taken shape. And again it was Boyer (1996) who helped give us our conceptual bearings. In the same posthumous essay in which he warns against higher education's becoming a purely "private benefit" (p. 14), he also reviews the four kinds of scholarship proposed in Scholarship Reconsidered (1990), 
namely, the scholarships of discovery, integration, teaching, and application. His discussion of the last of these eventually brings him to the conclusion "that in the century ahead, higher education in this country has an urgent obligation to become more vigorously engaged in the issues of our day" [emphasis added] (p. 17). Soon the phrase "scholarship of application" disappears, only to be replaced by the phrase "scholarship of engagement" (p. 18), and it is with this concept that the essay ends:

Increasingly, I'm convinced that ultimately, the scholarship of engagement also means creating a special climate in which the academic and civic cultures communicate more continuously and more creatively with each other, helping to enlarge what anthropologist Clifford Geertz describes as the universe of human discourse and enriching the quality of life for all of us. (p. 20)

This conviction that a scholarship of engagement ultimately aims at nothing less than "enriching the quality of life for all of us" finds its institutional equivalent in something Boyer (1994) had described two years earlier as the "New American College":

This New American College would organize cross-disciplinary institutes around pressing social issues. Undergraduates at the college would participate in field projects, relating ideas to real life. Classrooms and laboratories would be extended to include health clinics, youth centers, schools, and government offices. Faculty members would build partners with practitioners who would, in turn, come to campus as lecturers and student advisers. (p. A48)

For like the scholarship of engagement, the New American College "would be committed to improving, in a very intentional way, the human condition" (Boyer, 1994, p. A48). Like the scholarship of engagement, it would redefine academic excellence, embracing social relevance without abandoning intellectual rigor. In the little more than five years since Boyer left us with these guiding formulations, a small but increasing number of individual teacher-scholars as well as an ever more significant number of academic institutions have attempted to explore and embody the vision Boyer sketched.

It is not possible in an essay of this length even to begin to do justice to the breath and depth of the civic engagement movement as it has developed in the academy over the past ten years. Hence, a few suggestive indicators will have to suffice. Over the last three years alone, Campus Compact, the only national 
higher education organization whose sole purpose is to promote public and community service, particularly academically based service, grew by $30 \%$ to over 750 member colleges and universities (Campus Compact, 2001). During approximately the same period of time, the American Association for Higher Education (AAHE) completed a series of 18 monographs on service-learning in the academic disciplines (Zlotkowski, 1997-2000). It was the largest publishing venture in AAHE's history, and in the end drew upon the work of over 400 teacher-scholars from many different sectors of American higher education. The last few years have also seen major engagement initiatives launched by the New England Research Center for Higher Education, the Council of Independent Colleges, the American Association of Community Colleges, the National Association of State Universities and Land-Grant Colleges, and over half a dozen national disciplinary associations. Indeed, in direct response to Boyer's New American College vision, a group calling itself the Associated New American Colleges was formed.

What has made possible much of this work is generous funding from a host of public and private sources. Although many associate federal sponsorship of national and community service programs with the Clinton administration, it was actually the first George Bush that laid the foundation for them with his Commission on National and Community Service in 1990. Clinton then built upon and expanded this foundation into the Corporation on $\mathrm{Na}$ tional Service (CNS). Learn and service funding, though limited in the context of the overall CNS program, has been especially important in helping colleges and universities develop institutional structures capable of facilitating and sustaining academic engagement efforts. Funds made available through the Community Outreach Partnership Centers (COPC) Program at the Department of Housing and Urban Development, initiated in 1994, have played a similar role. It is one indication of the growth of national interest in engagement initiatives that bipartisan efforts are currently underway to increase federal funding for community-based student work.

Private foundations have also stepped up the plate. The Pew Charitable Trusts awarded Campus Compact several million dollars to develop a pyramid of service-learning, with programming specifically designed for institutions and faculty at different levels of experience with engaged work. Ford, Kellogg, Kettering, and Lilly have funded a complementary set of initiatives around community partnering and civic discourse. The Atlantic Philanthropies have invested in a variety of efforts related to higher education reform and civic renewal. 


\section{Faculty Considerations}

By this point, I think it should be clear why academic renewal through civic engagement is ultimately a faculty affair. As a Campus Compact report authored by Tim Stanton (1990), then associate director of the Haas Center at Stanford University, made clear, faculty participation in engagement, "in supporting student service efforts and in setting an example of civic participation and leadership through their own efforts" (p. 1), is critical to any strategy to promote effective and sustainable academic-civic partnerships.

And yet, despite this seemingly self-evident fact, many schools have, nonetheless, set about trying to claim Boyer's mantel without addressing the serious faculty development issues that mantel implies. Presidential proclamations laced with statistics on the number of student volunteer hours provided to the community, economic measures to benefit housing stock in local neighborhoods, new "urban research" institutes, strong community service traditions maintained through religious affiliations or specially endowed philanthropic halls or houses, donations of sporting equipment and notquite cutting-edge technology to local youth groups-these initiatives, as valuable and as admirable as they are, cannot by themselves constitute the kind of academic engagement Boyer envisioned and American society needs. They are the equivalent of those personal and private expressions of comfort and grief that appeared everywhere across American campuses in the wake of September 11. While meaningful and even necessary, such expressions failed to draw upon the academy's core function: the creation and dissemination of knowledge. Leaving rank-and-file faculty free to close the classroom or the office door and to continue with business as usual, they can actually divert attention from what is in many instances a serious lack of vision and a distressing failure of nerve.

One of the few university presidents to recognize and address the critical importance of developing an ethos of engagement in and through the work of mainstream faculty is Judith Ramaley, who first at Portland State University and later at the University of Vermont sought to implement Boyer's vision in a comprehensive, sustainable way. In an article titled "Nurturing the 'Engaged University," "Ramaley (2000) shares some of what she has learned about the process of winning faculty support for "activities that promote civic responsibility and sustain campus-community engagement" (p. 12).

She begins by noting that, in her experience, "10 to 15 percent of the faculty or staff on campus already have a broad repertoire of interests... consistent with the full realization of engagement." A second group, roughly double in size, has "a genuine interest in new ways of doing things but want 
clear signals [of support] ... if they venture into new territory, in this case, literally, into the community." Group three, approximately the same size as group two, see the new agenda as a fad or institutional whim, "certain [to] disappear when the new president/provost/dean moves on to greener pastures." Finally, there is "a small number (maybe 10 percent) of the faculty or staff... certain that the new agenda or the new modes are not legitimate faculty work" (Ramaley, 2000, p. 50).

According to Ramaley (2000), each of the last three groups has its own distinctive "energy barrier" which must be addressed if its members are to get on board:

The boundary between the committed [group one] and the cautious [group two] is defined by a disciplinary barrier and discipline-based definitions of research and scholarship... The border between the cautious and the skeptical [group three] is maintained by the lack of convincing evidence that the new ways or the new agenda works better than the old one... The resisters [group four] are protected by a fear of the risk of change itself.... Different strategies are needed to overcome each barrier. (p. 12)

My own experience in working with faculty from hundreds of institutions largely confirms this analysis. On every campus there is a core of faculty already aware of the significance and the potential of community-based academic work. Furthermore, in many cases, this core is composed largely of, on the one hand, young, tenure-track or part-time faculty and, on the other, senior professors. Those faculty closest to a tenure application and decision are most conspicuously missing.

By far the largest group of faculty I encounter belong to group two: their openness to change and/or their sense that change is needed sparks a degree of genuine interest. However, what they need to move forward is a sense that others in their field have already demonstrated the feasibility and value of acting on that interest. It was for this group in particular that AAHE's 18-volume series on service-learning in the academic disciplines (Zlotkowski, 1997-2000) was created, and it is this group that has profited most from AAHE and Campus Compact's efforts to support engaged scholarship in and through the national disciplinary societies.

It is when a dean or an academic vice president makes mandatory departmental representation at a presentation or workshop on engagement that I most often encounter members of group three. Quite legitimately, they demand to see "proof" that community-based work has real academic value. 
Fortunately, thanks to the work of a growing number of researchers (Astin, Vogelgesang, Ikeda, \& Yee, 2000; Eyler \& Giles, 1999; Harkavy, Puckett, \& Romer, 2000) that proof is increasingly easy to produce. Still, the fact that these "skeptics" seem largely uninterested in research that suggests serious epistemological and pedagogical questions regarding traditional classroom practices may render their calls for a culture of evidence somewhat disingenuous. In any event, it is those faculty from this group who, through some circumstance, are able to experience personally the heightened sense of significance and efficacy community-based work brings that become its most enthusiastic proponents. As for faculty from group four, I myself have had relatively little contact with them since they lack sufficient interest to initiate contact on their own and possess sufficient power not to need to do so to please others.

\section{The POD CONNECTION}

By this point, I imagine it is clear to most readers how POD members could contribute significantly to the civic renewal of American higher education. As the professionals responsible for faculty development, they are well positioned to collaborate with Campus Compact and AAHE both in bringing the engagement-related resources developed thus far to the faculty on their campuses and in creating additional resources based on their own expertise. Indeed, without access to the professional and organizational opportunities POD members represent, advancing the national engagement agenda will be slow and difficult. On most campuses there currently exists a complete disconnect between faculty development activities and efforts to promote a scholarship of engagement. A collaborative agenda could begin by addressing several essential tasks.

First and foremost, faculty need to understand more clearly the difference between ordinary civic contributions and the scholarship of engagement. As Boyer (1996) noted in the same essay in which he introduced the scholarship of engagement,

When we speak of applying knowledge we do not mean "doing good," although that's important. Academics have their civic functions, which should be honored, but by scholarship of application we mean having professors become what Donald Schon of MIT has called "reflective practitioners," moving from theory to practice, and from practice back to theory, which in fact makes theory, then, more authentic... (p. 17) 
Since then, many individual colleges and universities have gone on to draw essentially the same distinction (New England Resource Center for Higher Education, n.d.). Especially important in this regard are 1) the distinction between the more or less routine application of existing knowledge (a form of consulting) and the generation of new knowledge through a theorypractice dialectic, and 2) the distinction between community service, even if sponsored by a course, and academically rigorous service-based learning or service-learning. So long as faculty continue to conflate generic public assistance with the development of greater conceptual understanding through activities that benefit the public, challenges to the professional legitimacy of the scholarship of engagement will continue to distract attention from its creative utilization.

Closely related to this primary distinction is the ability to identify engagement opportunities that speak appropriately to the focus of a faculty member's expertise. It was to jumpstart this activity, at least with regard to teaching, that the AAHE monograph series (Zlotkowski, 1997-2000) was created, and it remains the single most useful resource available to faculty developers working with particular disciplinary constituencies. Indeed, to build on a faculty development strategy developed by a longtime POD member, Deborah DeZure (1996), Coordinator of Faculty Programs at the University of Michigan, one can easily imagine an entire program built around departmental workshops. As DeZure (1996) writes:

While useful in many ways ... centralized [faculty development] services are often underused by faculty, rejected by many as too remote from their disciplinary teaching concerns. For many faculty, teaching means teaching history or teaching music or teaching biology. For them, instructional development should become more disciplinary, engaging these faculty by exploring issues of teaching in the context of their departmental expectations and their disciplinary values and modes of discourse. (p. 9)

Drawing upon the monograph series and other engaged resources created by the national disciplinary associations, one could effortlessly adapt DeZure's strategy to introduce the scholarship of engagement to faculty in every academic area, if not every academic department.

Few researchers have studied the academic department more thoroughly than Jon Wergin (2001), Professor of Educational Studies at Virginia Commonwealth University. Recently, Wergin turned his attention to the issue of 
effective faculty incentives, only to conclude that talk of special, extrinsic incentives can be misleading:

More than forty years of research on faculty motivation has resulted in some remarkably consistent findings. Over and over again this research has found that those of us who choose to be faculty are driven by a relatively small number of motives: autonomy, community, recognition, efficacy. (p. 50)

Viewing this list from the standpoint of the scholarship of engagement (in all its forms), one can conclude that items one and two should not represent barriers to such work since autonomy, which Wergin (2001) glosses as "the freedom to grow in ways that contribute to the common good" (p. 50), is not threatened and community is probably enhanced. However, recognition and efficacy do represent barriers, and of the two it is recognition that is most often discussed.

Although no one who has spent much time with faculty interested in engaged work can deny that institutional recognition, especially as it applies to tenure and promotion, is an issue of fundamental concern, there is probably little that most POD members can do about it. Over the last five years, more and more colleges and universities wishing to move in an engaged direction have begun revising their tenure and promotion guidelines to recognize community-based work. However, efficacy, the sense that one is being effective, rarely comes up directly in conversations with would-be engaged faculty, and yet, it can be no less decisive than recognition. Indeed, according to Blackburn and Lawrence (1995), "... self-efficacy ... mattered more than any other variable in any category [of factors affecting faculty motivation]. It was significant in 26 instances at one time or another in every institutional type and academic discipline" (p. 281).

Very few of today's faculty have had, in the course of their ordinary graduate school and post-graduate work, any opportunity to develop either the awareness or the skills necessary for effective community outreach. While many of the skills they have developed remain relevant, when community enters the picture, the picture becomes especially complex. It is here that POD members could make a major contribution to the scholarship of engagement, first, by helping to identify what the additional skills are that it requires, and, second, by designing strategies and programs that allow faculty to develop those skills. Here, it seems to me, one finds ample room for theoretical and operational innovation. What do successful academy-community partnerships look like, and how does one form them? What models are available? How does 
one document community-based work? How does one assess its success from an academic, public, and institutional standpoint? What is the role of reflection in learning to learn from experience? How does one lead student reflection? How does one deal with the "messiness" inherent in such work?

Until now, there has been relatively little effort to train faculty to do work that more and more institutions are coming to regard as important. Dale Rice at Eastern Michigan Universiry, Bob Bringle and Julie Hatcher at Indiana University-Purdue University Indianapolis, and a few others have pioneered faculty development models in theory and/or in practice (Bringle \& Hatcher, 1995; Rice \& Stacey, 1997; Zlotkowski, 1998). In 1992, Portland State University (Driscoll, 1998) began working toward an organizational structure that would allow faculty development, community partnerships, and assessment to share the same space and support each other. Unfortunately, despite the university's widely acknowledged success, few other institutions have succeeded in learning from its example. POD involvement could help change that.

\section{Conclusion}

Gene Rice, Director of AAHE's Forum on Faculty Roles and Rewards, and Ernest Boyer's collaborator in redefining legitimate faculty work, has often recalled how heretical the idea of faculty development seemed in the early 1970s. The scholarship of engagement currently occupies a similar position, and, if the comparison holds true, may in 20 years seem as self-evident as faculty development does now. At least we can hope that is the case. In 1998, a special task force of the American Political Science Association (APSA) released a statement on civic education in the 21 st century. It reads in part:

We start with the evidence suggesting mounting political apathy in the United States.... Long-term efforts to reverse [this] must obviously address many possible causes. We do, however, take as axiomatic that current levels of political knowledge, political engagement, and political enthusiasm are so low as to threaten the vitality and stability of democratic politics in the United States. (p. 636)

While this warning directs itself explicitly to forms of political engagement, other formulations in the document make clear that it is concerned with civic engagement in a broad as well as a narrow sense. Certainly its summary response speaks to that broader sense of engagement; namely, that there is an urgent need to " $[t]$ each the motivation and competence to engage actively in public problem solving" (p. 636). This was precisely what most of my 
Bentley College colleagues did not know how to do in the days immediately following September 11. We have little reason to believe faculty at other institutions were any more prepared to move beyond general discussions and expressions of personal concern. To be sure, these are important. But by themselves they will not lead to academic renewal or higher education reform.

Over the past decade AAHE and Campus Compact have made a major investment in helping both faculty and institutions learn to practice and to teach public problem solving-the scholarship of engagement. It is my sincere hope that members of POD will regard publication of this essay as an invitation to join that effort.

\section{REFERENCES}

American Political Science Association (APSA). (1998). Task force on civic education in the 21 st century: Expanded articulation statement: $A$ call for reactions and contributions. PS: Politics and Political Science, 31 (3), 636.

Astin, W. A., Vogelgesang, L. J., Ikeda, E. K., \& Yee, J. A. (2000). How service learning affects students. Los Angeles, CA: University of California at Los Angeles, Higher Education Research Institute.

Blackburn, R. T., \& Lawrence, J. H. (1995). Faculty at work: Motivation, expectation, satisfaction. Baltimore, MD: The Johns Hopkins University Press.

Boyer, E. L. (1990). Scholarship reconsidered: Priorities of the professoriate. Princeton, NJ: The Carnegie Foundation for the Advancement of Teaching.

Boyer, E. L. (1994, March 9). Creating the new American college. The Chronicle of Higher Education, p. A48.

Boyer, E. L. (1996). The scholarship of engagement. Journal of Public Service \& Outreach, 1(1), 11-20.

Boyte, H. C. (2000). The struggle against positivism. Academe, 86, 46-51.

Bringle, R. G., \& Hatcher, J. A. (1995). A service-learning curriculum for faculty. Michigan Journal of Community Service Learning, 2, 112-122.

Campus Compact. (2001). A conceptual framework for building the pyramid of servicelearning and civic engagement: Creating an engaged campus. Providence, RI: Campus Compact.

DeZure, D. (1996). Closer to the disciplines: A model for improving teaching within departments. AAHE Bulletin, 48(6), 9-12. 
Driscoll, A. (1998). Comprehensive design of community service: New understanding, options, and vitality in student learning at Portland State University. In E. Zlotkowski (Ed.), Successful service-learning programs: New models of excellence in higher education (pp. 150-168). Bolton, MA: Anker.

Eyler, J., \& Giles, D. E., Jr. (1999). Where's the learning in service-learning? San Francisco, CA: Jossey-Bass.

Harkavy, I., Puckett, J., \& Romer, D. (2000). Action research: Bridging action and Research. Michigan Journal of Community Service Learning, special issue, 113-118.

Higher Education Research Institute (HERI). (1999). National norms: 1998-1999 HERI faculty survey report. Los Angeles, CA: University of California at Los Angeles Graduate School of Education and Information Studies. Retrieved April 16, 2001 from http://www.gseis.ucla.edu/heri/heri.html

Howard, D. L. (2001, September 20). Teaching through tragedy. The Chronicle of Higher Education. Retrieved April 2, 2001, from http://chronicle.com/jobs/ 2001/09/2001092001c.htm

Kerr, C. (1963, 1994). The uses of the university. Cambridge, MA: Harvard University Press.

Kolvenbach, Rev. S. J. (2000, October). The service of faith and the promotion of justice in American Jesuit higher education. Paper presented at the Conference on Commitment to Justice in Jesuit Higher Education, Santa Clara University, CA.

Lewontin, R. C. (1997). The Cold War and the transformation of the academy. In A. Schiffrin (Ed.), The Cold War and the university: Toward an intellectual history of the postwar years (pp. 1-34). New York, NY: The New Press.

Lind, M. (1995). To have and have nor: Notes on the progress of the American class war. Harper's, 250(1741), 35-47.

New England Resource Center for Higher Education. (n.d.). Program on faculty professional service and academic outreach. Boston, MA: University of Massachusetts, Boston.

Newman, F. (2000). Saving higher education's soul. Change, 33, 16-23.

Ramaley, J. A. (2000). Embracing civic responsibility. AAHE Bulletin, 52 (7), 9-13.

Rice, D., \& Stacey, K. (1997). Small group dynamics as a catalyst for change: A faculty development model for academic service-learning. Michigan Journal of Community Service Learning, 4, 64-71.

Schon, D. A. (1995). The new scholarship requires a new epistemology. Change, 27 (G), 27-34. 
Stanton, T. K. (1990). Integrating public service with academic study: The faculty role. Providence, RI: Campus Compact.

Sullivan, W. M. (n.d.). Institutional identity and social responsibility. Washington, DC: Council on Public Policy Education.

Wergin, J. F. (2001). Beyond carrots: What really motivates faculty. Liberal education, $87(1), 50-53$.

Zlotkowski, E. (Ed.). (1997-2000). AAHE series on service-learning in the disciplines. Washington, DC: American Association for Higher Education.

Zlotkowski, E. (1998). A service learning approach to faculty development. In J. P. Howard \& R. Rhodes (Eds.), Service learning pedagogy and research (pp. 81-89). San Francisco, CA: Jossey-Bass.

\section{Contact:}

Edward Zlotkowski

MOR 328

Bentley College

175 Forest Street

Waltham, MA 02452-4705

Voice (781) 891-2592

Email ezlotkowski@bentley.edu

Edward Zlotkowski is a Professor of English at Bentley College, a Senior Associate at the American Association for Higher Education (AAHE), and a Senior Faculty Fellow at Campus Compact. In 1990, he founded the Bentley Service-Learning Project, an institution-wide program that has involved in its work all of the college's undergraduate academic departments, more than a quarter of its full-time faculty, and several thousand students. In 1995, he was named a senior associate at AAHE and in that capacity has served as general editor of a monograph series exploring the relationship between service-learning and academic disciplines/disciplinary areas. In 1999, he was named a senior faculty fellow at Campus Compact, responsible for developing professional development opportunities in service-learning for provosts and deans as well as a series of summer institutes for engaged academic departments. He has published and spoken extensively on a wide range of service-learning topics and regularly uses a service-learning approach in his own teaching. 